\title{
Analisa Keawetan Kayu Terap (Artocarpus elasticus Reinw) dengan Pengawet Koopers Formula 7 Menggunakan Metode Penguburan
}

\author{
Durability Analysis of Terap (Artocarpus Elasticus Reinw) Wood Using Coopers \\ Formula 7 Preservative Conducted by a Graveyard Test
}

\author{
Joko Prayitno* \\ Jurusan Teknologi Pertanian, Politeknik Pertanian Negeri Samarinda, Indonesia. \\ *Corresponding Author: Jokopra047@gmail.com
}

\begin{abstract}
Abstrak
Penelitian daya tahan kayu Terap (Artocarpus elasticus Reinw) terhadap serangan hama kayu khususnya dari golongan rayap tanah menggunakan garam pengawet jenis Koopers Formula 7 , menggunakan metode graveyard test (uji penguburan) bertujuan untuk mengetahui persentase serangan rayap tanah, self retention bahan pengawet, serta absorbsi bahan pengawet pada kayu Terap. Bahan yang digunakan dalam penelitian ini adalah kayu Terap (A. elasticus Reinw) yang direndam menggunakan bahan pengawet formula 7 Koopers dengan konsentrasi $3 \%, 5 \%$, dan $7 \%$. Hasil penelitian menunjukkan bahwa perlakuan pengawetan dengan pengawet Koopers Formula 7 pada kayu Terap dapat memberikan nilai retensi, daya serap dan setelah sampel diawetkan kemudian ditimbun di tanah diketahui bahwa nilai persentase serangan jamur pewarna dan pembusuk adalah masing-masing $25 \%, 15 \%$ dan $5 \%$.
\end{abstract}

Kata kunci: keawetan, terap, metode penguburan

\begin{abstract}
Research on wood endurance of Terap (Artocarpus elasticus Reinw) to organizational attack of pest of wood specially from faction creep land ground using preservative salt type of Koopers Formula 7, using obsequies method (graveyard test) aim to know the percentage of faction creep land ground attack, selfretention of preservative, and absorbtion of preservative at Terap wood. Materials which are used in this research is wood of Terap (A. elasticus Reinw) invited using of Koopers formula 7 preservatives at different concentration of $3 \%, 5 \%$, and $7 \%$. Result of research indicate that treatment of pickling with preservative of Koopers Formula 7 at wood of Terap can assign value of retention, absorbtion and after samples conserved then buried in land ground for 30 days known that value percentage of colourant and rotting fungi attack are equal to each $25 \%, 15 \%$ and $5 \%$, respectively.
\end{abstract}

Keywords: durability, terap, graveyard test

\section{PENDAHULUAN}

Kebutuhan kayu oleh masyarakat dari tahun ke tahun semakin meningkat, khususnya yang memiliki keawetan tinggi. Tetapi ketergantungan kepada jenis kayu awet tersebut menyebabkan jumlahnya terbatas sehingga produksinya terbatas dan harganya sangat mahal, selain itu penggunaan jenis kayu lainnya menjadi tidak efisien.

Oleh karena itu perlu dicari peluang untuk memanfaatkan kayu non komersial walaupun kelas awetnya lebih rendah kemudian diawetkan sebagai alternatif penggunaannya, misalnya jenis terap (Artocaifus elasticus Reinw) yang potensinya cukup besar dan cepat tumbuh (fast growing species) terdapat di hutan sekunder muda/tua.

Selain itu upaya pengawetan kayu akan memberikan keuntungan ganda yaitu jenis kayu yang kurang awet dapat dimanfaatkan yang berarti juga bahwa penggunaan sumber alam menjadi lebih efisien dan masa pakai (service life) kayu bertambah sehingga biaya perbaikan atau perombakan dapat ditekan. Pemakaian bahan kimia tertentu sebagai bahan pengawet kayu sangat dimungkinkan, yang penting bahan tersebut beracun terhadap organisme perusak kayu dan harganya murah. Jenis pengawet yang larut air dan cara rendaman adalah suatu 
pilihan yang sederhana, mudah dan terjangkau.

Penelitian ini bertujuan untuk mengetahui keawetan jenis terap dengan pengawet Koopers Formula 7 yang direndam 30 hari dan dikubur dalam tanah 30 hari. Sehingga diketahui nantinya persentase serangan rayap lanah, retensi dan absorbsi pengawet terhadap kayu tersebut.

Sedangkan hasil penelitian ini dapat dijadikan bahan pertimbangan dalam penentuan/pemilihan bahan pengawet maupun bahan kayu sebagai alternatif penggunaannya bagi masyarakat.

\section{METODE PENELITIAN}

\section{Waktu dan Tempat}

Penelitian dilaksanakan selama 3 (tiga) di bulan dan dilaksanakan di Laboratorium Pengawetan Kayu, Jurusan Pengolahan Hasil Hutan, Politeknik Pertanian Negeri Samarinda.

\section{Alat dan Bahan}

Alat yang digunakan adalah gergaji untuk membuat sample uji, cangkul untuk membuat lubang kubur (grave), sekop, timbangan elektrik, gelas ukur 1000 ml, meteran, kaliper, bak rendaman kayu sampel, kaea pembesar (Loupe), pemberat (beban), alat tulis, kalkulator.

Bahan yang digunakan terdiri dari bahan pengawet Koopers Formula 7, kayu terap dan merkubung, air, jamur dan rayap tanah

\section{Prosedur Penelitian}

\section{Pembuatan Larutan Bahan Pengawet}

Campurkan Koopers Formula 7 yang berbentuk garam berwarna kuning yang telah ditimbang sebanyak 30 gram dimasukkan dalam gelas ukur $1000 \mathrm{ml}$ untuk membuat larutan konsentrasi 3\%. Masukkan $30 \mathrm{gr}$ Kooper Fornula 7 dalam gelas ukur dan 'tambahkan air hingga mencapai 1000 ml per skala gelas.

Demikian pula untuk konsentrasi $50 \%$ bahan pengawet yang dimasukkan ke gelas ukur sebanyak $50 \mathrm{gr}$, dan konsentrasi $7 \%$ bahan pengawetnya ditimbnag $70 \mathrm{gr}$ dimasukkan ke dalam gelas ukur kemudian diisi air sampai $1000 \mathrm{ml}$.

\section{Persiapan Kayu (Sampel Uji)}

a. Memilih jenis terap dan merkubung yang kira-kira $45 \mathrm{~cm}$ yang diambil di hutan lindung Bukit Suharto

b. Kayu tersebut masing-masing dibuat contoh uji dengan ukuran $2 \mathrm{~cm} \times 2 \mathrm{~cm}$ $x 30 \mathrm{~cm}$ sebanyak 100 buah, yang terdiri dari 30 sampel untuk kontrol (tanpa bahan pengawet) dan 90 jenis sampel jenis terap (konsentrasi 3\% 30 buah, 5\% 30 buah dan $7 \% 30$ buah sampel).

c. Contoh uji sernuanya ditimbang (100 potong sampel) sesuai tanda pada contoh kode konstrasi.

d. Masing-masing sampel kayu dimasukkan dalam baskom rendaman sesuai kode jenis dan konsentrasi bahan pengawetnya.

e. Perendaman di lakukan selama 1 minggu untuk semua sampel kecuali 30 sampel kontrol dari kode jenis kayu tidak direndam.

f. Setelah 1 minggu direndam 120 sampel dari 3 macam konsentrasi diangkat dan ditiriskan.

g. Setelah tidak menetes lagi air pada sampel-sampel tersebut kemudian ditimbang dan dikering angin-anginkan selama 1 bulan.

h. Setelah semua sampel kering udara, volume sampel diukur dengan kaliber.

i. Sampel-sampel siap dihitung retensi dan absorbsinya.

\section{Pengujian Graveyard Test Terhadap Organisme Perusak Kayu (Jamur).}

Organisme perusak kayu yang dipakai untuk menguji keampuhan atau ketahanan kayu adalah jamur pewarna dan pelapuk kayu yang terserang di penggergajian (sawmill). Tahap- tahap pengujiannya adalah:

a. Sampel yang berjumlah 100 buah dimasukkan ke lubang (kubur) sistem Grave Yard Test, yaitu membuat lubang terdiri dari lubang untuk sampel kontrol dan Lubang untuk sampel konsentrasi $3 \%, 5 \%$ dan $7 \%$. Lubang kubur dibuat sedalam kira-kira $30 \mathrm{~cm}$ di lapangan terbuka sehingga memungkinkan organisme menyerang karena adanya udara dan kelembaban yang selalu diinginkan oleh organisme tersebut.

b. Penguburan sampel dilakukan selama 12 bulan, tetapi dalam penelitian ini diamati sampai 2 bulan saja, karena waktu 
penelitian yang hanya 3 bulan termasuk persiapan bahan kayu. Sedangkan pengamatan sampai seterusnya yaitu (10 bulan) dilanjutkan terus pada penelitian berikutnya. Jadi bersifat continue dengan perbedaan interval waktu.

c. Cara untuk mengetahui terjadinya serangan atau kontaminasi jamur /rayap tanah adalah dengan menggunakan loupe yang dilakukan setelah 1 bulan dikubur dalam tanah dan dihitung dengan rumus.

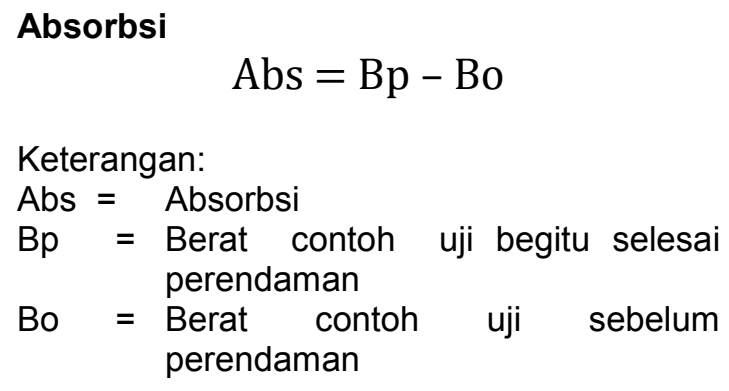

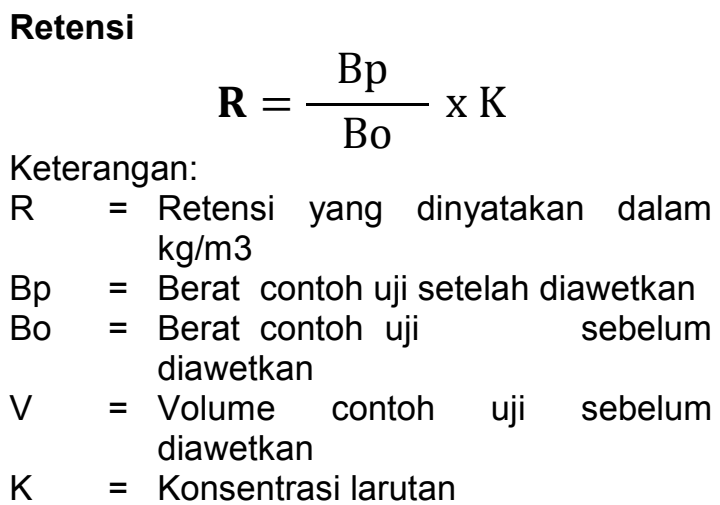

Persentase Serangan

Keterangan:

$$
\mathbf{P S}=\frac{\Sigma \mathrm{S}}{\Sigma \mathrm{A}} \times \mathrm{K}
$$

PS = Persentase serangan

$\Sigma S=$ Jumlah sampel yang terserang

$\Sigma \mathrm{A}=$ Jumlah sampel yang tidak diserang

Tabel 1. Nilai Rataan Absorbsi (Gram) Retensi $\left(\mathrm{gr} / \mathrm{cm}^{3}\right)$ dan Persentase Serangan Organisme Perusak Kayu (\%) pada Kayu Terap (Artocarpus elasticus Reinw) dengan Pengawet Koopers Formula 7.

\begin{tabular}{llcccc}
\hline & & \multicolumn{4}{c}{ Konsentrasi larutan (\%) } \\
\cline { 3 - 6 } No. & Parameter & 0 & 3 & 5 & 7 \\
\hline 1 & Absorbsi & - & 19,50 & 16,31 & 16,20 \\
2 & Retensi & - & 0,005 & 0,007 & 0,009 \\
3 & Persentase & $100^{* * *}$ & $25^{*}$ & $15^{* *}$ & $5^{* *}$ \\
\hline Keterangan: & \multirow{2}{*}{ * Brown stringy dan mold, } & ** Jamur biru (blue stain), & \multirow{2}{*}{${ }^{* * *}$ White rot, brown rot dan soft rot }
\end{tabular}

\section{HASIL DAN PEMBAHASAN}

Hasil

Berdasarkan pengamatan dan perhitungan terhadap nilai absorbsi, retensi dan persentase serangan organisme terhadap jenis kayu terap (Artocarpus elasticus Reinw) dengan bahan pengawet Koopers Formula 7, disajikan pada Tabel 1.

\section{Pembahasan}

Hasil penelitian menunjukkan bahwa nilai absorbsi kayu terap dengan balian pengawet Koopers Formula 7 dan konsentrasi yang berbeda diperoleh rataan yang berbeda pula. Pada konsentrasi larutan $3 \%$ absorbsinya $19,50 \mathrm{gr}$, sedangkan konsentrasi $5 \%$ absorbsi adalah $16,31 \mathrm{gr}$ dan konsentrasi $7 \%$ absorbsinya 16,20 dari angka tersebut diketahai bahwa konsentrasi terendah yaitu $3 \%$ adalah larutan yang paling sedikit kadar bahan pengawetnya, berupa senyawa-senyawa yang larut air sehingga relatif lebih permeable sehingga nilai absorbsi lebih tinggi yaitu 19,50 gr dibanding dengan larutan konsentrasi 5\% dan 7\% dikarenakan larutan dengan kadar pengawet yang lebih besar diduga adanya mekanisme 
ketidaklarutan di dalam senyawa larutan yang semula larut dalam air, di dalam kayu diubah menjadi bahan beracun yang sukar larut. Menurut Nicholas (1988) reaksi mekanisme tersebut di atas memerlukan waktu kira-kira 4 minggu pada $25{ }^{0} \mathrm{C}$, keadaan demikian tentu saja menghambat proses absorbsi yaitu penyerapan garamgaram pengawet ke dalam kayu.

Perbedaan nilai absorbsi menurut Alex (2000), bahwa besarnya absorbsi larutan bahan pengawet sangat ditentukan oleh tiga faktor yaitu jenis bahan pengawet jenis kayu yang diawetkan dan cara pengawetannya serta besarnya konsentrasi larutan.

Berdasarkan hasil penelitian dalam satuan gram $/ \mathrm{cm}^{3}$ karena ukuran sampel/contoh uji adalah $2 \mathrm{~cm} \times 2 \mathrm{~cm} \times 30$ $\mathrm{cm}$, maka diperoleh nilai rata-rata retensi dari konsentrasi larutan yang berbeda, untuk konsentrasi $3 \%$ nilai retensinya paling rendah yaitu $0,005 \mathrm{gr} / \mathrm{cm}$ dan konsentrasi $5 \%$ nilai retensinya $0,007 \mathrm{gr} / \mathrm{cm} 3$ serta konsentrasinya $7 \%$ nilai retensinya adalah yang paling tinggi yaitu $0,009 \mathrm{gr} / \mathrm{cm}$ ).

Tinggi rendahnya nilai retensi sangat dipengaruhi oleh konsentrasi larutan yang digunakan, dari penelitian di atas dapat dilihat bahwa larutan konsentrasi $7 \%$ ternyata menghasilkan nilai retensi yang lebih besar dari konsentrasi $3 \%$ dan $5 \%$, hal ini sesuai dengan pernyataan Hunt dan Garrath (1986) bahwa konsentrasi yang tinggi akan menghasilkan retensi yang tinggi pula.

Tetapi menurut Nicholas (1988) bahwa retensi yang rendah dapat digunakan pada kayu di atas tanah, sedangkan jika kayu yang retensi tinggi hanya akan menghasilkan limbah dan sifat-sifat yang tidak diinginkan. Kayu yang diawetkan dengan garam tinggi akan terlalu keras dan rapuh, lagi pula akan menyebabkan bahaya pijar jika kena kebakaran rumput.

Persentase serangan jamur yang diamati pada penelitian ini menunjukkan tingkat serangan jamur terhadap kayu tetap yang telah diawetkan dengan konsentrasi 3\% $5 \%$ dan $7 \%$ larutan Koopers Formula 7 dan telah dikubur dalam tanah sedalam $30 \mathrm{~cm}$ selama 30 hari, diperoleh nilai rata-rata persentase serangan $100 \%$ terhadap sampel kontrol (yaitu sampel yang tidak diawetkan). Jenis jamur yang menyerang pada sampel kontrol adalah white rot, soft rot maupun brown rot, di mana sampel dipenuhi benang hyfa (micelium) berwarna putih sampai coklat dan akhirnya hijau menjadi lunak. Sedangkan persentase serangan jamur pada konsentrasi $3 \%$ nilainya $25 \%$ berupa jamur biru (blue stain), sedangkan kayu terap yang diawetkan dengan konsentrasi $5 \%$, persentase 15\% juga berupa jamur biru dan konsentrasi $7 \%$ nilai persentase serangannya $5 \%$.

Dari nilai persentase di atas dapat diketahui bahwa tingginya konsentrasi menghasilkan persentasi serangan yang kecil, hal ini menunjukkan bahwa kayu yang diawetkan dengan zefensi bahan pengawet yang tinggi akan mampu menolak organisme perusak kayu seperti jamur pewarna atau pelapuk kayu. Peneliti pengawetan kayu terdahulu telah meneliti bahwa konsentrasi larutan dengan bahan pengawet Impralit CKB sangat mampu dan ampuh menahan serangan jamur, tetapi contoh uji (sampel)nya, tidak . bersentuhan langsung dengan tanah dikuburkan dalam tanah.

Sedangkan dari penelitian ini contoh uji sengaja dikubur selama 30 hari, dibiarkan kontak dengan tanah kemudian baru di amati, ternyata menghasilkan data persentase serangan yang lebih besar, walaupun menggunakan konsentrasi larutan yang sama $(5 \%)$ dan yang $7 \%$ dalam tanah sedalam $30 \mathrm{~cm}$ selama 30 hari, diperoleh nilai rata-rata persentase serangan $100 \%$ terhadap sampel kontrol (yaitu sampel yang tidak diawetkan). Dengan jenis jamur yang menyerang pada sampel kontrol adalah white rot, soft rot maupun brown rot, di mana sampel dipenuhi benang hyfa (micelium) berwarna putih sampai coklat dan akhirnya hijau menjadi lunak. Sedangkan persentase serangan jamur pada konsentrasi $3 \%$ nilainya $25 \%$ berupa jamur biru (blue stain), sedangkan kayu terap yang diawetkan dengan konsentrasi $5 \%$, persentase $15 \%$ juga berupa jamur biru dan konsentrasi $7 \%$ nilai persentase serangannya $5 \%$.

Dari nilai persentase di atas dapat diketahui bahwa tingginya konsentrasi menghasilkan persentasi serangan yang kecil, hal ini menunjukkan bahwa kayu yang diawetkan dengan retensi bahan pengawet yang tinggi akan mampu menolak organisme perusak kayu seperti jamur pewarna atau pelapuk kayu. Peneliti pengawetan kayu terdahulu telah meneliti bahwa konsentrasi larutan dengan bahan 
pengawet Impralit CKB sangat mampu dan ampuh menahan serangan jamur, tetapi contoh uji (sampel)nya, tidak bersentuhan langsung dengan tanah dikuburkan dalam tanah. Sedangkan dari penelitian ini contoh uji sengaja dikubur selama 30 hari, dibiarkan kontak dengan tanah kemudian baru di amati, ternyata menghasilkan data persentase serangan yang lebih besar, walaupun menggunakan konsentrasi larutan yang sama (5\%) dan yang $7 \%$.

Hal ini didukung oleh pendapat Nandika dkk (1989) bahwa perkembangan jamur pewarna bisa terjadi sangat cepat apalagi kalau kondisi kelembaban dan suhu sesuai dengan sifat perkembangannya.

Dari hal ini akan menyebabkan kerusakan pada kayu yang lebih parah karena ancaman serangan rayap_ tanah di kemudian hari, biasanya rayap tanah menyerang kayu yang kondisi kayunya sudah mengalami serangan jamur pelapuk lebih dulu karena rusaknya jaringan dinding sel kayu yang telah dirombak oleh hyfa jamur masuk ke dalam kayu, sehingga banyak tersedia selulosa yang menjadi makanan bagi rayap tersebut.

\section{KESIMPULAN}

1. Semakin tinggi konsentrasi larutan maka semakin rendah nilai absorbsinya

2. Semakin tinggi konsentrasi larutan maka semakin tinggi nilai retensinya

3. Keawetan kayu terap yang dikubur dalam tanab masih dapat diserang oleh jamur pewarna dan pelapuk kayu walaupun sudah diawetkan dengan pengawet Koopers Formula 7

4. Kayu terap hasil penelitian ini diduga tahan terhadap serangan jamur apabila dalam penggunaannya tidak menyentuh tanah.

\section{DAFTAR PUSTAKA}

Alex, T. 2000. Pengaruh Cara Pengawetan di Industri Perum Perumnas Semarang. Standar Terhadap Keawetan dan Kekuatan Kayu Bangunan. Tesis. Program Pasca Sarjana Universitas Gajah Mada. Yogyakarta.
Nicholas, D.D. 1.973. Wood Deterioration and Its Prevention by Preservative Treatment Vol. I. Syracuce University Press. New York.

Sugianto.1969. Kimia Organik. Penerbit Widjaja. Jakarta.

Suranto, 2002. Pengawetan Kayu. Bahan dan Metoda. Kanisius. Yogyakarta.

Tambunan, B. dan D. Nandika. 1989. Deteriorasi Kayu oleh Faktor Biologis. Depdikbud Ditjen Dikti PAU Bioteknologi IPB. Bogor.

Willeitner, H. and W. Liese. 1992. Wood Protection in Tropical Countries. A Manual on The Know How. Deutsche Zusamenarbeit (GTZ) GmbH. Technical Cooperation Federal Republic of Germany. Escborn. 